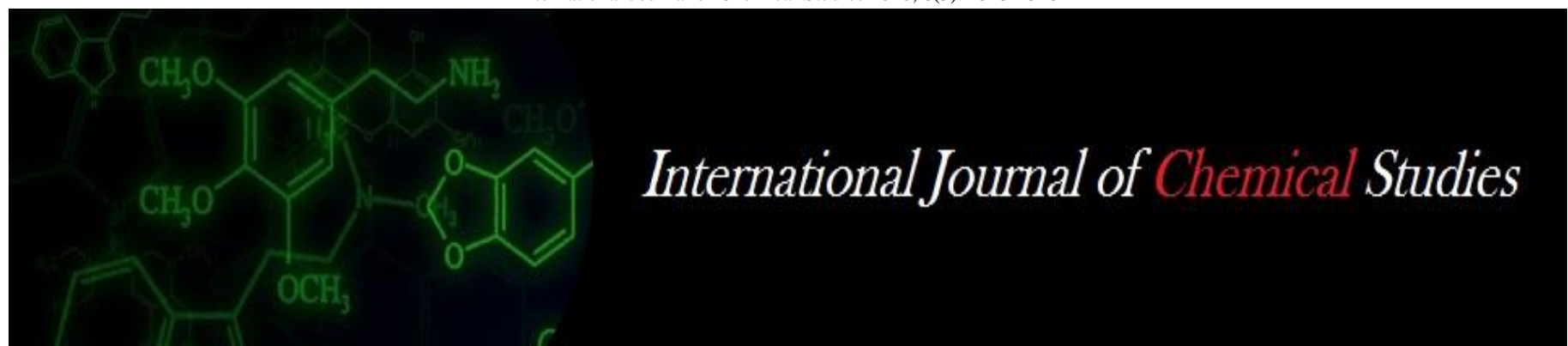

P-ISSN: 2349-8528

E-ISSN: 2321-4902

www.chemijournal.com

IJCS 2020; 8(5): 1523-1528

(C) 2020 IJCS

Received: 26-07-2020

Accepted: 04-07-2020

Dev Narayan

Department of Agronomy, Indira Gandhi Krishi

Vishwavidyalaya, Raipur,

Chhattisgarh, India

Dr. Vivek Kumar Tripathi Department of Agronomy, Indira Gandhi Krishi

Vishwavidyalaya, Raipur,

Chhattisgarh, India

Dr. Anil Kumar Verma

Department of Agronomy, Indira Gandhi Krishi

Vishwavidyalaya, Raipur, Chhattisgarh, India
Corresponding Author: Dev Narayan

Department of Agronomy, Indira Gandhi Krishi

Vishwavidyalaya, Raipur,

Chhattisgarh, India

\section{Effect of soil and foliar application of zinc on growth, yield attributes and yield of rice (Oryza sativa $\mathbf{L}$.)}

\author{
Dev Narayan, Dr. Vivek Kumar Tripathi and Dr. Anil Kumar Verma
}

DOI: https://doi.org/10.22271/chemi.2020.v8.i5u.10516

\begin{abstract}
The experiment was performed in Randomized block design with 4 replications by taking 6 treatments viz., foliar application of zinc @ $250 \mathrm{ml} \mathrm{ha}^{-1}, 500 \mathrm{ml} \mathrm{ha}^{-1}, 750 \mathrm{ml} \mathrm{ha}^{-1}$, combination of basal application of zinc sulphate @ $10 \mathrm{~kg} \mathrm{ha}^{-1}$ + foliar application of zinc @ $750 \mathrm{ml} \mathrm{ha}^{-1}$ or alone basal application of zinc sulphate @ $10 \mathrm{~kg} \mathrm{ha}^{-1}$ and Untreated control. Maximum growth parameters viz., number of leaves plant ${ }^{-1}$, number of tillers plant ${ }^{-1}$, dry matter accumulation, leaf area index and yield attributes viz., number of effective tillers $\mathrm{m}^{-2}$, filled grains panicle ${ }^{-1}$, panicle weight, panicle length, number of filled grain per panicle, grain yield and straw yield was noted with foliar application of zinc @ $750 \mathrm{ml} \mathrm{ha}^{-1}$ which was comparable with foliar application of zinc @ 500 or $250 \mathrm{ml} \mathrm{ha}^{-1}$ or combination of basal application of zinc sulphate @ $10 \mathrm{~kg} \mathrm{ha}^{-1}+$ foliar application of zinc @ $750 \mathrm{ml} \mathrm{ha}^{-1}$ and alone basal application.
\end{abstract}

Keywords: Oryza sativa, application of zinc, kharif

\section{Introduction}

Rice (Oryza sativa L.) is one of the most staple food crops for more than half of the world population by providing $25 \%$ calories and $20 \%$ protein. More than 2 billion people get $60-70 \%$ of their energy requirement from rice and its derived products. Rice (Oryza sativa L.) is one of the important cereal crops which play a vital role in food security. More than 90 per cent of total rice production in the world is consumed by Asian countries, where it is a staple food for a majority of the population (Mohanty, 2013) ${ }^{[9]}$. During 2018-19, India has recorded production of rice to the tune of 99.3 million tonnes but considering the present growth rate of population as well as per capita consumption, the demand for rice has been projected as 156 million tonnes by 2030 (Anonymous, 2016) ${ }^{[3]}$. Rice is the world's most important cereal and potentially important source of zinc. Zinc is one of the most important micronutrient which is essential for plant growth especially for rice grown under submerged condition. Plant uptake zinc in $\mathrm{Zn}^{2+}$ form; it is a micronutrient but plays a vital role in growth and metabolism of plant. Zinc is a major component and activator of several enzymes involved in metabolic activities (Klug and Rhodes, 1987) ${ }^{[7]}$. It is essentially required for protein synthesis and gene expression in plants (Cakmak, 2000) ${ }^{[4]}$. It has been estimated that about $10 \%$ of the proteins in biological system need zinc for their structural and functional integrity (Andreini et al., 2006) ${ }^{[2]}$. Rice grown in flooded conditions has higher requirement of zinc because the availability of other nutrients in submerged condition increases which decreases zinc availability to crop. Plants take up zinc in the form of $\mathrm{Zn}^{2+}$ ions. Diffusion is believed to be the dominant mechanism for $\mathrm{Zn}^{2+}$ transport to plant roots (Rashid, 2001) ${ }^{[14]}$. Zinc deficiency causes multiple symptoms that usually appear 2 to 3 weeks after transplanting of rice seedlings. Deficient leaves develop brown blotches and streaks that may fuse to cover older leaves entirely, plants remain stunted and in severe cases may die, while those that recover will show substantial delay in maturity and reduction in yield. It's deficiency leads to appearance of dusty brown spots on upper leaves, stunted growth of plants, decrease tillering ability and increases spikelets sterility. Deficiency symptoms are prolonged during early growth stage due to immobilization of zinc, it's deficiency in rice crop is commonly known as Khaira disease. 


\section{Materials and Methods}

The study on "Effect of soil and foliar application of zinc on growth, yield attributes and yield of rice (Oryza sativa L.)" was performed during the season of kharif, 2019 at Instructional cum Research farm in Indira Gandhi Krishi Vishwavidyalaya, Raipur (Chhattisgarh). The experimental site is located in the central part of Chhattisgarh at longitude $81.36^{\circ} \mathrm{E}$ and latitude $21.16^{\circ} \mathrm{N}$ with an altitude of 298 meters above the mean sea level. The experiment was performed in Randomized block design with 4 replications by taking 6 treatments viz., foliar application of zinc @ $250 \mathrm{ml} \mathrm{ha}^{-1}, 500$ $\mathrm{ml} \mathrm{ha} \mathrm{h}^{-1}, 750 \mathrm{ml} \mathrm{ha} \mathrm{a}^{-1}$, combination of basal application of zinc sulphate@10 kg ha ${ }^{-1}$ + foliar application of zinc@ $950 \mathrm{ml}$ $\mathrm{ha}^{-1}$ or alone basal application of zinc sulphate @ $10 \mathrm{~kg} \mathrm{ha}^{-1}$ and Untreated control. In this research recorded growth parameters viz., number of leaves plant ${ }^{-1}$, number of tillers plant $^{-1}$, dry matter accumulation, leaf area index and the crop from each net plot was harvested separately and panicle weight, panicle length, number of filled grain per panicle, grain yield and straw yield recorded and expressed in $\mathrm{q} \mathrm{ha}^{-1}$.

\section{Result and Discussion}

Field experiment on "Effect of soil and foliar application of zinc on growth parameters, yield attributes, yield and economics of rice" conducted during kharif season of 2019 at Research cum Instructional Farm, I.G.K.V., Raipur (C.G.).
The objective was to assess the impact of zinc on performance of rice. In this chapter, results are presented with the help of tables and graphics and discuss the cause and effect relationship from observations recorded during the course of investigation along-with established scientific views of national and international research workers.

\section{Growth parameters \\ Plant height}

The plant height was recorded at 30,60 and 90 days after transplanting (DAT) and presented in Table 1. Plant height was increased with the advancement of crop age. Irrespective of the treatments, plant height increased 49.69 per cent from 30 to 60 DAT and 5.13 per cent between $60-90$ DAT. The effect of treatments on plant height was not noticed at 30 DAT. Foliar application of zinc @ 750 or 500 or $250 \mathrm{ml} \mathrm{ha}^{-1}$ or combination of basal application of zinc sulphate@10 kg $\mathrm{ha}^{-1}+$ foliar application of zinc @ $750 \mathrm{ml} \mathrm{ha}^{-1}$ or alone basal application of zinc sulphate @ $10 \mathrm{~kg} \mathrm{ha}^{-1}$ were being at par to each other and produced the tallest plants than that of untreated control during both period of observations i.e. 60 and 90 DAT. Application of zinc reduced the disease infection supported with sufficient nutrients increased the cell division causing more stem elongation resulting in increased the plant height. Similar findings have been also reported by Mumba and Ambara (2013) ${ }^{[10]}$.

Table 1: Effect of soil and foliar application of zinc on plant height of rice

\begin{tabular}{|c|c|c|c|}
\hline \multirow{2}{*}{ Treatment } & \multicolumn{3}{|c|}{ Plant height (cm) } \\
\hline & 30 DAT & 60 DAT & 90 DAT \\
\hline Foliar application of liquid zinc $39.5 \% @ 250 \mathrm{ml} \mathrm{ha}^{-1}$ at tillering and panicle initiation stage & 68.85 & 104.41 & 110.16 \\
\hline Foliar application of liquid zinc $39.5 \% @ 500 \mathrm{ml} \mathrm{ha}^{-1}$ at tillering and panicle initiation stage & 68.88 & 104.56 & 110.20 \\
\hline Foliar application of liquid zinc $39.5 \% @ 750 \mathrm{ml} \mathrm{ha}^{-1}$ at tillering and panicle initiation stage & 70.75 & 105.09 & 110.83 \\
\hline $\begin{array}{c}\text { Application of Zinc Sulphate 33\% @ } 10 \mathrm{~kg} \mathrm{ha}^{-1} \text { as basal fb liquid zinc 39.5\% @ } 500 \mathrm{ml} \text { at tillering and } \\
\text { panicle initiation stage }\end{array}$ & 70.82 & 107.90 & 110.43 \\
\hline Application of Zinc Sulphate $33 \%$ @ $10 \mathrm{~kg} \mathrm{ha}^{-1}$ as basal & 70.66 & 104.40 & 110.05 \\
\hline Untreated control & 68.60 & 100.18 & 107.02 \\
\hline SEm \pm & 1.70 & 1.35 & 0.71 \\
\hline $\mathrm{CD}(\mathrm{P}=0.05)$ & NS & 4.06 & 2.13 \\
\hline
\end{tabular}

\section{Number of leaves}

Number of leaves plant ${ }^{-1}$ recorded at 30, 60 and 90 days after transplanting (DAT) and influenced due to zinc application in rice (Table 2). In general, number of leaves increased up to 60 DAT and declined thereafter. Significant effect of treatments on number of leaves was not noted at 30 DAT. Foliar application of zinc @ 750 or 500 or $250 \mathrm{ml} \mathrm{ha}^{-1}$ or combination of basal application of zinc sulphate@10 kg ha ${ }^{1}+$ foliar application of zinc @ $750 \mathrm{ml} \mathrm{ha}^{-1}$ or alone basal application of zinc sulphate @ $10 \mathrm{~kg} \mathrm{ha}^{-1}$ were found to be equally effective and superior over untreated control for the production of leaves. The lowest number of leaves was observed under untreated control which was comparable with foliar application of zinc @ $250 \mathrm{ml} \mathrm{ha}^{-1}$ and basal application of zinc sulphate @ $10 \mathrm{~kg} \mathrm{ha}^{-1}$ at 60 DAT. Application of zinc favourably influenced the cell division and enlargement which facilitated more number of leaves. This is in accordance with the findings of Rana et al. (2014) ${ }^{[13]}$.

Table 2: Effect of soil and foliar application of zinc on number of leaves of rice

\begin{tabular}{|c|c|c|c|c|}
\hline \multirow{2}{*}{ Treatment } & \multicolumn{4}{|c|}{ Number of leaves } \\
\hline & 30 DAT & 60 DAT & 90 DAT & At harvest \\
\hline Foliar application of liquid zinc $39.5 \% @ 250 \mathrm{ml} \mathrm{ha}^{-1}$ at tillering and panicle initiation stage & 32.75 & 52.75 & 16.95 & 13.16 \\
\hline Foliar application of liquid zinc $39.5 \% @ 500 \mathrm{ml} \mathrm{ha}^{-1}$ at tillering and panicle initiation stage & 33.25 & 55.75 & 17.85 & 13.30 \\
\hline Foliar application of liquid zinc $39.5 \% @ 750 \mathrm{ml} \mathrm{ha}^{-1}$ at tillering and panicle initiation stage & 35.33 & 56.75 & 17.75 & 15.75 \\
\hline $\begin{array}{c}\text { Application of Zinc Sulphate 33\% @ } 10 \mathrm{~kg} \mathrm{ha}^{-1} \text { as basal fb liquid zinc 39.5\% @ } 500 \mathrm{ml} \text { at } \\
\text { tillering and panicle initiation stage }\end{array}$ & 36.33 & 56.00 & 18.00 & 15.39 \\
\hline Application of Zinc Sulphate 33\% @ $10 \mathrm{~kg} \mathrm{ha}^{-1}$ as basal & 33.75 & 52.10 & 16.85 & 13.15 \\
\hline Untreated control & 31.92 & 48.50 & 15.53 & 11.25 \\
\hline SEm \pm & 2.30 & 1.56 & 0.43 & 0.48 \\
\hline $\mathrm{CD}(\mathrm{P}=0.05)$ & NS & 4.68 & 1.30 & 1.45 \\
\hline
\end{tabular}

\section{Leaf area index (LAI)}

Leaf area index was observed at 30,60 and 90 DAT and presented in Fig.1. Irrespective of the treatments, leaf area index increased with increasing crop age up to 60 DAT. The intensity of increasing of LAI was more between 30 to 60 DAT than that of 60-90 DAT. Leaf area index was the highest 
under the foliar application of zinc @ $750 \mathrm{ml} \mathrm{ha}^{-1}$ which was closely followed by basal application of zinc sulphate @ 10 $\mathrm{kg} \mathrm{ha}^{-1}+$ foliar application of zinc @ $750 \mathrm{ml} \mathrm{ha}^{-1}$. The lowest LAI was noticed under untreated control at all the stages of observations. Application of zinc increased the number of leaves and leaf area and subsequently increased the LAI. This also the conformity of the findings of Amanullah et al. (2016) [1].

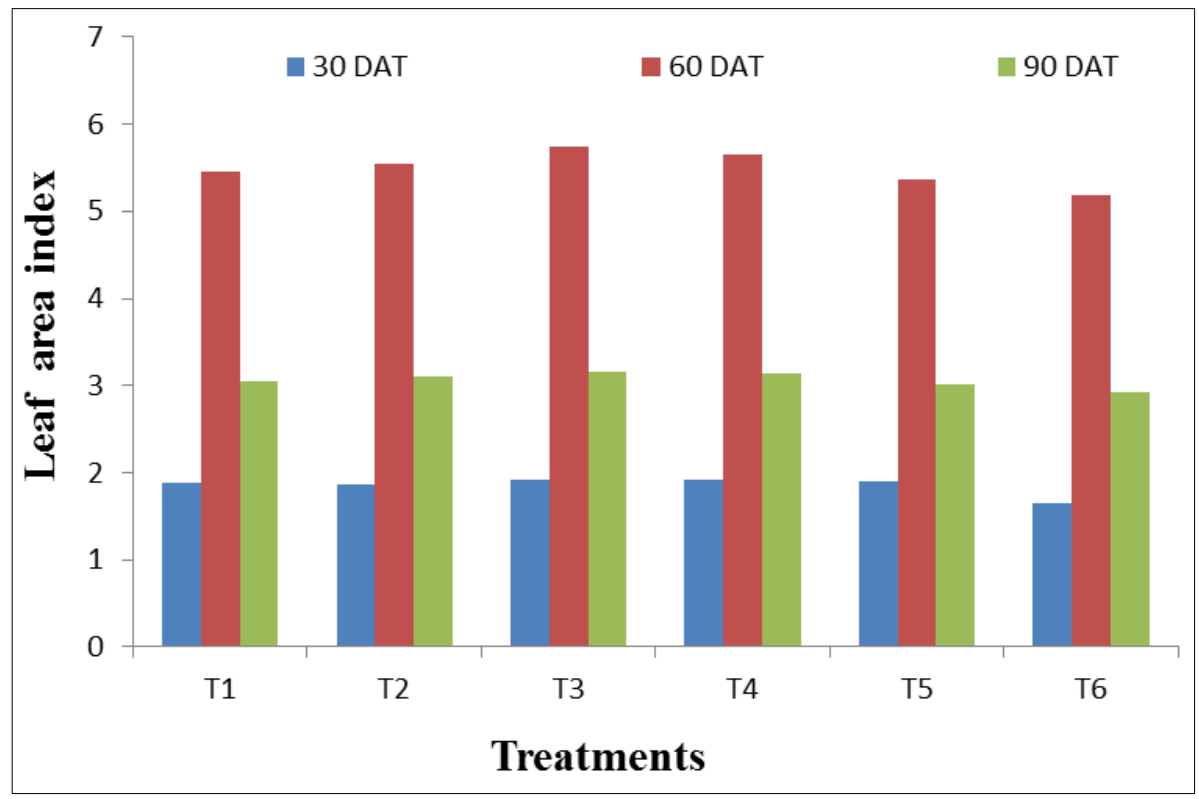

Fig 1: Effect of soil and foliar application of zinc on Leaf area index of rice

\section{Number of tillers}

Number of total tillers plant ${ }^{-1}$ was counted at 30, 6090 DAT and at harvest (Table 3). It increased up to 60 DAT and thereafter decreased till harvest. Irrespective of the treatments, tillers appeared at 30,60, 90 DAT and at harvest was 10.66, $9.38,8.21$ and 7.00, respectively. Basal application of zinc sulphate@10 kg ha-1 produced significantly higher number of tillers than that of other treatment except basal application of zinc sulphate@10 kg ha ${ }^{-1}+$ foliar application of zinc @ $750 \mathrm{ml} \mathrm{ha}^{-1}$ and foliar application of zinc @ 750 or 500 or 250 $\mathrm{ml} \mathrm{ha}^{-1}$ at 30 DAT. Further advancement of crop age, foliar application of zinc @ 750 or 500 or $250 \mathrm{ml} \mathrm{ha}^{-1}$ or combination of basal application of zinc sulphate @ $10 \mathrm{~kg} \mathrm{ha}^{-}$ ${ }^{1}+$ foliar application of zinc @ $750 \mathrm{ml} \mathrm{ha}^{-1}$ or alone basal application of zinc sulphate @ $10 \mathrm{~kg} \mathrm{ha}^{-1}$ were statistically at par and obtained significantly higher number of tillers as compared to untreated control. Higher growth due to increased photosynthetic rate under application of zinc might be the reasons for increasing the number of tillers. Similar findings were also reported by Ghani et al. (1990) ${ }^{[6]}$.

Table 3: Effect of soil and foliar application of zinc on number of tillers of rice

\begin{tabular}{|c|c|c|c|c|}
\hline \multirow{2}{*}{ Treatment } & \multicolumn{4}{|c|}{ Number of tillers } \\
\hline & 30 DAT & 60 DAT & 90 DAT & At harvest \\
\hline Foliar application of liquid zinc $39.5 \% @ 250 \mathrm{ml} \mathrm{ha}^{-1}$ at tillering and panicle initiation stage & 10.08 & 9.43 & 8.13 & 7.11 \\
\hline Foliar application of liquid zinc $39.5 \% @ 500 \mathrm{ml} \mathrm{ha}^{-1}$ at tillering and panicle initiation stage & 10.33 & 9.50 & 8.50 & 7.14 \\
\hline Foliar application of liquid zinc $39.5 \% @ 750 \mathrm{ml} \mathrm{ha}^{-1}$ at tillering and panicle initiation stage & 11.08 & 9.90 & 8.98 & 7.27 \\
\hline $\begin{array}{c}\text { Application of Zinc Sulphate 33\% @ } 10 \mathrm{~kg} \mathrm{ha}^{-1} \text { as basal fb liquid zinc } 39.5 \% \text { @ } 500 \mathrm{ml} \text { at } \\
\text { tillering and panicle initiation stage }\end{array}$ & 11.16 & 9.62 & 8.53 & 7.17 \\
\hline Application of Zinc Sulphate 33\% @ $10 \mathrm{~kg} \mathrm{ha}^{-1}$ as basal & 11.39 & 9.33 & 8.08 & 7.07 \\
\hline Untreated control & 9.91 & 8.50 & 7.05 & 6.25 \\
\hline SEm \pm & 0.31 & 0.23 & 0.31 & 0.21 \\
\hline $\mathrm{CD}(\mathrm{P}=0.05)$ & 0.92 & 0.70 & 0.92 & 0.62 \\
\hline
\end{tabular}

\section{Dry matter accumulation}

Dry matter accumulation plant ${ }^{-1}$ biomass was recorded at 30 , 60 and 90 DAT and at harvest (Table 4). Irrespective of treatments, the rate of dry matter accumulation was at lower pace up to 30 DAT, after that, it got momentum and increases up to harvest. At all the stages of observations, dry matter accumulation under foliar application of zinc @ 750 or 500 or $250 \mathrm{ml} \mathrm{ha}^{-1}$ or combination of basal application of zinc sulphate@10 kg ha ${ }^{-1}+$ foliar application of zinc @ $750 \mathrm{ml}$ $\mathrm{ha}^{-1}$ and alone basal application of zinc sulphate @ $10 \mathrm{~kg} \mathrm{ha}^{-1}$ were comparable to each other and found to be superior over untreated control except 30 DAT. At this stage, basal application of zinc sulphate @ $10 \mathrm{~kg} \mathrm{ha}^{-1}$ produced higher dry matter accumulation which was at par with combination of basal application of zinc sulphate @ $10 \mathrm{~kg} \mathrm{ha}^{-1}+$ foliar application of zinc @ $750 \mathrm{ml} \mathrm{ha}^{-1}$ and foliar application of zinc@ $950 \mathrm{ml} \mathrm{ha}^{-1}$. The lowest dry matter accumulation was registered under untreated control which was comparable with foliar application of zinc @ 500 or $250 \mathrm{ml} \mathrm{ha}^{-1}$ at 30 DAT. More number of leaves and LAI reflected through increased in photosynthetic activities which ultimately increased the dry matter accumulation under the application of zinc. These results are also corroborated by Kumar et al. (2017) ${ }^{[8]}$. 
Table 4: Effect of soil and foliar application of zinc on Dry matter accumulation g plant ${ }^{-1}$ of

rice

\begin{tabular}{|c|c|c|c|c|}
\hline \multirow{2}{*}{ Treatment } & \multicolumn{4}{|c|}{ Dry matter accumulation $\left(\mathrm{g} \mathrm{plant}^{-1}\right)$} \\
\hline & 30 DAT & 60 DAT & 90 DAT & At harvest \\
\hline Foliar application of liquid zinc $39.5 \% @ 250 \mathrm{ml} \mathrm{ha}^{-1}$ at tillering and panicle initiation stage & 4.96 & 20.80 & 39.99 & 62.18 \\
\hline Foliar application of liquid zinc $39.5 \% @ 500 \mathrm{ml} \mathrm{h}^{-1}$ at tillering and panicle initiation stage & 4.72 & 21.59 & 41.47 & 63.40 \\
\hline Foliar application of liquid zinc $39.5 \%$ @ $750 \mathrm{ml} \mathrm{ha}^{-1}$ at tillering and panicle initiation stage & 5.16 & 22.06 & 42.40 & 65.53 \\
\hline $\begin{array}{c}\text { Application of Zinc Sulphate } 33 \% \text { @ } 10 \mathrm{~kg} \mathrm{ha}^{-1} \text { as basal fb liquid zinc } 39.5 \% \text { @ } 500 \mathrm{ml} \text { at } \\
\text { tillering and panicle initiation stage }\end{array}$ & 5.91 & 22.58 & 42.26 & 64.87 \\
\hline Application of Zinc Sulphate 33\% @ $10 \mathrm{~kg} \mathrm{ha}^{-1}$ as basal & 6.07 & 20.02 & 39.63 & 62.02 \\
\hline Untreated control & 4.57 & 19.05 & 37.22 & 58.85 \\
\hline SEm \pm & 0.34 & 1.09 & 1.62 & 1.37 \\
\hline $\mathrm{CD}(\mathrm{P}=0.05)$ & 1.03 & 3.29 & 4.89 & 4.14 \\
\hline
\end{tabular}

\section{Crop growth rate and relative growth rate}

Crop growth rate (CGR) and relative growth rate RGR) was computed between 0-30, 30-60, 60-90 DAT and 90 DAT-at harvest and depicted through Fig.2 and 3. Irrespective of the treatments, CGR was increased with the increasing age of crop but it maximum between 30-60 DAT. CGR and RGR were highest under foliar application of zinc @ $750 \mathrm{ml} \mathrm{ha}^{-1}$, whereas, lowest CGR and RGR were observed under untreated control. Almost similar trend was noticed for all the stages of observations.

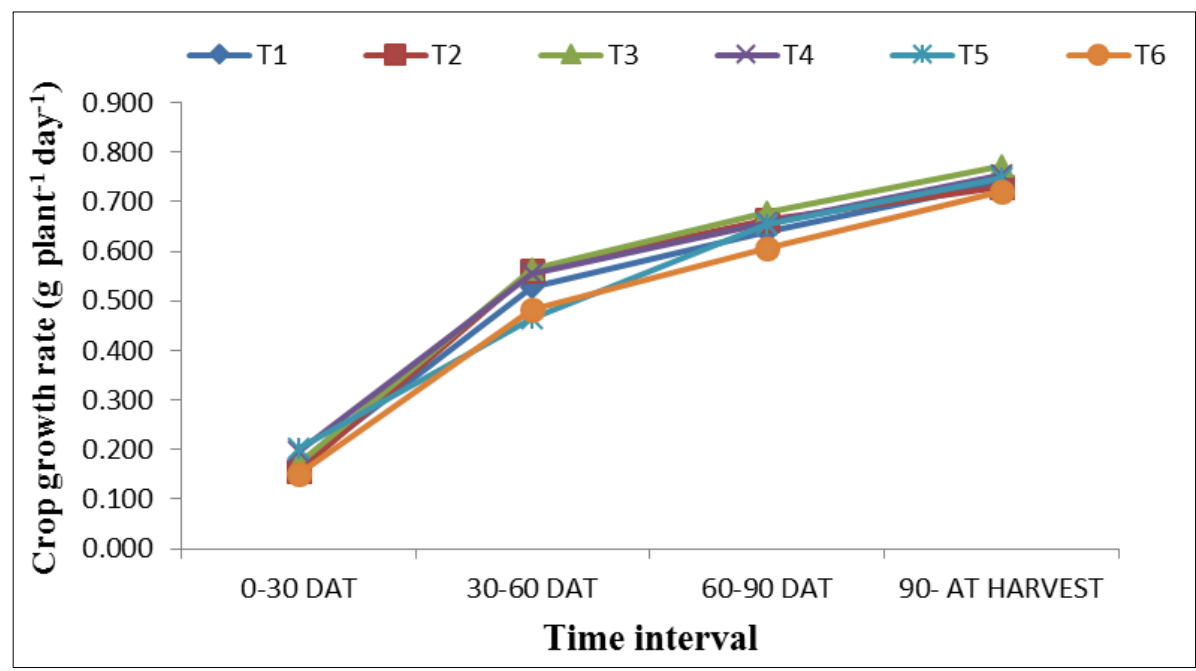

Fig 2: Effect of soil and foliar application of zinc on Crop growth rate of rice

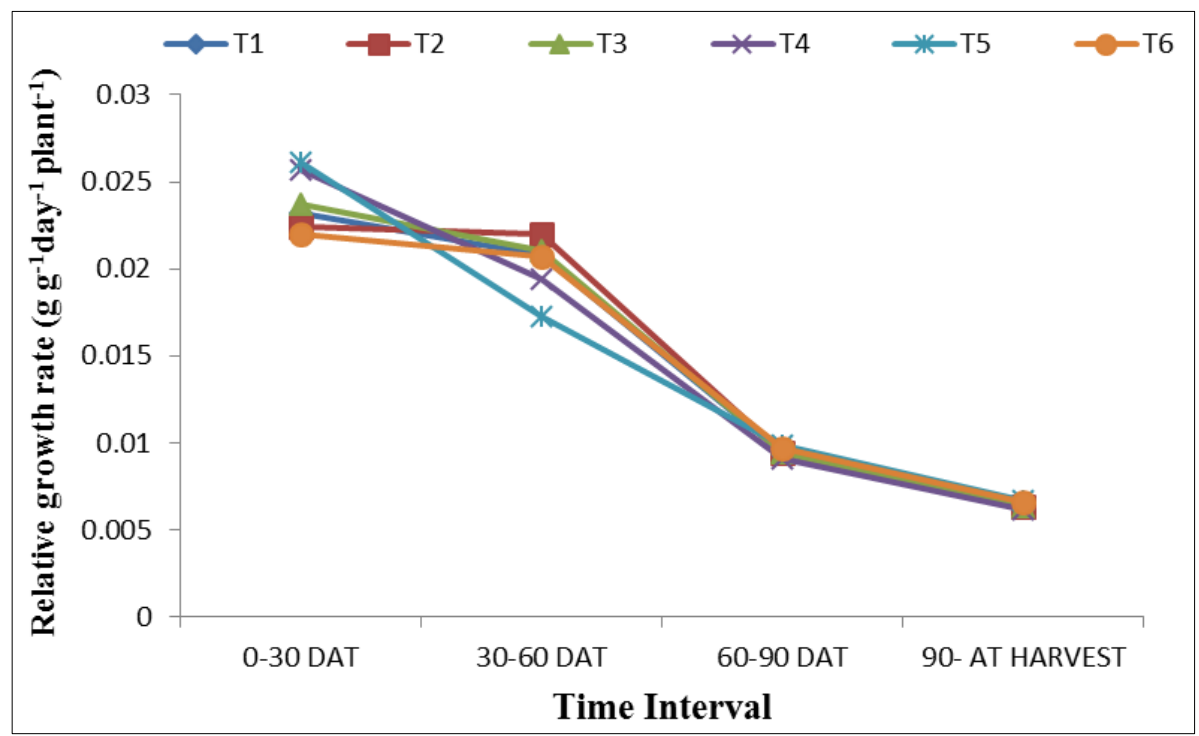

Fig 3: Effect of soil and foliar application of zinc on Relative growth rate of rice

\section{Yield attributes and Yield}

Effective tillers, panicle weight, panicle length, filled grains panicle-1, unfilled grains panicle-1 and test weight The data related to yield attributes- i.e. effective tillers, panicle weight and length, filled grains panicle ${ }^{-1}$, unfilled grains panicle ${ }^{-1}$ and test weight have been presented in Table 5 and Table 6. Panicle length and test weight was not affected due to different treatments. Foliar application of zinc @ 750 $\mathrm{ml} \mathrm{ha} \mathrm{h}^{-1}$ produced the highest number of effective tillers, panicle weight and number of filled grains panicle ${ }^{-1}$. The comparable performance of above parameters was observed with the foliar application of zinc @ 500 or $250 \mathrm{ml} \mathrm{ha}^{-1}$ or combination of basal application of zinc sulphate @ $10 \mathrm{~kg} \mathrm{ha}^{-}$ ${ }^{1}+$ foliar application of zinc @ $750 \mathrm{ml} \mathrm{ha}^{-1}$ and alone basal 
application of zinc sulphate @ $10 \mathrm{~kg} \mathrm{ha}{ }^{-1}$. Significant reduction in effective tillers, panicle weight and filled grains panicle $^{-1}$ was observed under untreated control but remained at par with foliar application of zinc @ $250 \mathrm{ml} \mathrm{ha}^{-1}$ and basal application of zinc sulphate @ $10 \mathrm{~kg} \mathrm{ha}^{-1}$ for panicle weight. The number of unfilled grains panicle ${ }^{-1}$ was higher under untreated control which was found comparable with foliar application of zinc @ $250 \mathrm{ml} \mathrm{ha}^{-1}$ and basal application of zinc sulphate@10 kg ha ${ }^{-1}$. Almost all yield attributes (effective tillers, panicle weight, filled grains panicle ${ }^{-1}$ and unfilled grains panicle ${ }^{-1}$ ) except panicle length and test weight were favourably influenced by the application of zinc. This might be due to efficient utilization of resources by reducing the disease incidence and subsequently increasing the plant dry biomass thereby increasing the yield attributes. Saha $e t a l$. (2016) also reported the similar findings.

Table 5: Effect of soil and foliar application of zinc on yield attributing characters of rice

\begin{tabular}{|c|c|c|c|}
\hline Treatment & \begin{tabular}{|c|}
$\begin{array}{c}\text { Effective tillers } \\
\left(\text { No. } \mathbf{~ m}^{-2}\right)\end{array}$ \\
\end{tabular} & $\begin{array}{c}\text { Panicle } \\
\text { Weight (g) }\end{array}$ & \begin{tabular}{|c|}
$\begin{array}{c}\text { Panicle length } \\
(\mathrm{cm})\end{array}$ \\
\end{tabular} \\
\hline Foliar application of liquid zinc $39.5 \% @ 250 \mathrm{ml} \mathrm{ha}^{-1}$ at tillering and panicle initiation stage & 300.25 & 2.65 & 22.11 \\
\hline Foliar application of liquid zinc $39.5 \% @ 500 \mathrm{ml} \mathrm{ha}^{-1}$ at tillering and panicle initiation stage & 307.00 & 2.78 & 22.28 \\
\hline Foliar application of liquid zinc $39.5 \% @ 750 \mathrm{ml} \mathrm{ha}^{-1}$ at tillering and panicle initiation stage & 313.50 & 2.88 & 22.93 \\
\hline $\begin{array}{c}\text { Application of Zinc Sulphate 33\% @ } 10 \mathrm{~kg} \mathrm{ha}^{-1} \text { as basal fb liquid zinc } 39.5 \% \text { @ } 500 \mathrm{ml} \text { at } \\
\text { tillering and panicle initiation stage }\end{array}$ & 308.25 & 2.79 & 22.69 \\
\hline Application of Zinc Sulphate 33\% @ $10 \mathrm{~kg} \mathrm{ha}^{-1}$ as basal & 299.85 & 2.61 & 21.77 \\
\hline Untreated control & 285.50 & 2.40 & 21.32 \\
\hline SEm \pm & 4.55 & 0.09 & 0.47 \\
\hline $\mathrm{CD}(\mathrm{P}=0.05)$ & 13.71 & 0.29 & NS \\
\hline
\end{tabular}

Table 6: Effect of soil and foliar application of zinc on yield attributing characters of rice

\begin{tabular}{|c|c|c|c|}
\hline Treatment & \begin{tabular}{|c|} 
Filled grain \\
panicle $^{-1}($ No. $)$
\end{tabular} & $\begin{array}{l}\text { Unfilled grains } \\
\text { panicle }^{-1} \text { (No.) }\end{array}$ & $\begin{array}{c}\text { Test } \\
\text { weight }(\mathrm{g})\end{array}$ \\
\hline Foliar application of liquid zinc $39.5 \% @ 250 \mathrm{ml} \mathrm{ha}^{-1}$ at tillering and panicle initiation stage & 90.05 & 13.75 & 27.28 \\
\hline Foliar application of liquid zinc $39.5 \% @ 500 \mathrm{ml} \mathrm{ha}^{-1}$ at tillering and panicle initiation stage & 91.40 & 13.15 & 28.43 \\
\hline Foliar application of liquid zinc $39.5 \% @ 750 \mathrm{ml} \mathrm{ha}^{-1}$ at tillering and panicle initiation stage & 91.95 & 12.10 & 27.85 \\
\hline $\begin{array}{c}\text { Application of Zinc Sulphate 33\% @ } 10 \mathrm{~kg} \mathrm{ha}^{-1} \text { as basal fb liquid zinc } 39.5 \% \text { @ @ } 500 \mathrm{ml} \text { at } \\
\text { tillering and panicle initiation stage }\end{array}$ & 91.90 & 12.65 & 28.13 \\
\hline Application of Zinc Sulphate 33\% @ $10 \mathrm{~kg} \mathrm{ha}^{-1}$ as basal & 89.45 & 13.85 & 27.88 \\
\hline Untreated control & 80.80 & 15.70 & 25.93 \\
\hline SEm \pm & 2.43 & 0.69 & 1.18 \\
\hline $\mathrm{CD}(\mathrm{P}=0.05)$ & 7.33 & 2.07 & NS \\
\hline
\end{tabular}

\section{Grain yield, straw yield and harvest index}

The data pertaining to grain yield, straw yield and harvest index presented in Table 7. Harvest index did not influenced significantly due to different treatments. Irrespective of treatments, grain yield was enhanced under application of zinc by 8.07 per cent compared to untreated control. The grain and straw yield was found comparable and significantly higher under foliar application of zinc @ 750 or 500 or 250 $\mathrm{ml} \mathrm{ha} \mathrm{H}^{-1}$ or combination of basal application of zinc sulphate @ $10 \mathrm{~kg} \mathrm{ha}^{-1}+$ foliar application of zinc @ $750 \mathrm{ml} \mathrm{ha}^{-1}$ and alone basal application of zinc sulphate @ $10 \mathrm{~kg} \mathrm{ha}^{-1}$ as compared to untreated control. The significantly reduction in grain and straw yield was observed under untreated control. A decrease in leaf area causes a reduction in area for interception and absorption of the specific wavelength of light necessary for photosynthesis resulted in reduction of root and plant dry biomass thereby reducing absorption of nutrients subsequently reducing the yield attributes, yield and harvest index. The plants under application of zinc had better partitioning of dry matter, which lead to increase in the number of effective tillers, filled grains panicle $^{-1}$ and decrease in the number of unfilled grains panicle ${ }^{-1}$ resultant in higher grain yield. These results are in agreement with the findings of Qaisrani (2011) ${ }^{[11]}$.

Table 7: Effect of soil and foliar application of zinc on grain yield, straw yield and harvest index of rice

\begin{tabular}{|c|c|c|c|}
\hline Treatment & $\begin{array}{c}\text { Grain yield } \\
\left(\mathrm{q} \mathrm{ha}^{-1}\right)\end{array}$ & $\begin{array}{c}\text { Straw yield } \\
\left(\mathrm{q} \mathrm{ha}^{-1}\right)\end{array}$ & $\begin{array}{c}\text { Harvest } \\
\text { index }(\%)\end{array}$ \\
\hline Foliar application of liquid zinc $39.5 \% @ 250 \mathrm{ml} \mathrm{ha}^{-1}$ at tillering and panicle initiation stage & 48.80 & 57.93 & 45.72 \\
\hline Foliar application of liquid zinc $39.5 \% @ 500 \mathrm{ml} \mathrm{ha}^{-1}$ at tillering and panicle initiation stage & 50.10 & 58.63 & 46.08 \\
\hline Foliar application of liquid zinc $39.5 \% @ 750 \mathrm{ml} \mathrm{ha}^{-1}$ at tillering and panicle initiation stage & 50.36 & 62.45 & 44.64 \\
\hline $\begin{array}{c}\text { Application of Zinc Sulphate 33\% @ } 10 \mathrm{~kg} \mathrm{ha}^{-1} \text { as basal fb liquid zinc } 39.5 \% \text { @ } 500 \mathrm{ml} \text { at tillering } \\
\text { and panicle initiation stage }\end{array}$ & 50.12 & 61.80 & 44.78 \\
\hline Application of Zinc Sulphate 33\% @ $10 \mathrm{~kg} \mathrm{ha}^{-1}$ as basal & 48.52 & 57.97 & 46.30 \\
\hline Untreated control & 45.88 & 52.97 & 46.41 \\
\hline SEm \pm & 0.81 & 1.62 & 0.61 \\
\hline $\mathrm{CD}(\mathrm{P}=0.05)$ & 2.43 & 4.89 & NS \\
\hline
\end{tabular}

\section{Conclusion}

Foliar application of zinc @ $750 \mathrm{ml} \mathrm{ha}^{-1}$ produced maximum growth parameters and grain yield of rice which was comparable with foliar application of zinc @ 500, $250 \mathrm{ml} \mathrm{ha}$
1, combination of basal application of zinc sulphate @ $10 \mathrm{~kg}$ $\mathrm{ha}^{-1}+$ foliar application of zinc @ $750 \mathrm{ml} \mathrm{ha}^{-1}$ and alone basal application. 


\section{References}

1. Amanullah, Inamullah, Shah Z, Khali SK. Phosphorus and zinc interaction influence leaf area index in fine versus coarse rice (Oryza sativa L.) genotype in NorthWest Pakistan. Journal of Plant Stress Physiology. 2016; 2:1-8.

2. Andreini C, Banci L, Rosato A. Zinc through the three domains of life. Journal of Proteome Research. 2006; 5:3173-3178.

3. Anonymous. Vision 2030. Indian Council of Agricultural Research, New Delhi, 2016, 4.

4. Cakmak I. Possible roles of zinc in protecting plant cells from damage by reactive oxygen species. New Phytology. 2000; 146:185-205.

5. Fageria NK, Moreira A, Coelho AM. Yield and yield components of upland rice as influenced by nitrogen sources. Journal Plant Nutrition. 2011; 34:361-370.

6. Ghani A, Shah M, Khan DR. Response of rice to elevated rates of zinc in mountainous areas of Swat. Sarhad Journal of Agriculture. 1990; 6:411-415.

7. Klug A, Rhodes D. Zinc finger: A Noval protein motif for nucleic acid recognition. Trends Biochemistry Science. 1987; 12:464-469.

8. Kumar D, Kumar R, Singh P, Kumar P. Effect of different Zinc management practices on growth, yield, protein content, nutrient uptake and economics on rice under partially reclaimed salt-affected soil. Journal of Pharmacognosy and Phytochemistry. 2017; 6(5):638-640.

9. Mohanty S. Trends in global rice consumptions. Rice Today. 2013; 12(1):44-45.

10. Muamba JK, Ambara GS. Effect of different levels of zinc on growth and uptake ability in rice zinc contrasting lines. Asian journal of plant science and research. 2013; 3(3):112-116.

11. Mustafa G, Ehsanullah Akhtar N, Qaisrani AS, Iqbal A, Khan ZH, Jabran $\mathrm{K}$ et al. Effect of zinc application on growth and yield of rice. International Journal for Agro Veterinary and Medical Sciences. 2011; 5(6):530-535.

12. Qaisrani SA. Effect of method and time of zinc application on growth and yield of rice (Oryza sativa L.). International Journal for Agro Veterinary and Medical Sciences. 2011; 5(6):530-535.

13. Rana WK, Khashif SR. Effect of different zinc sources and methods of application on rice yield and nutrient concentration in rice grain and straw. Journal Environment Agriculture Science. 2014; 1:9.

14. Rashid A. Secondary and micronutrients; Soil Science. National Book Foundation, Islamabad, 2001, 372-379.

15. Saha B, Saha S, Roy PD, Hazara GC, Das A. Zinc fertilization effects on Agromorphological and quality parameters of commonly grown rice. SAARC Journal of Agriculture. 2013; 11(1):105-120. 